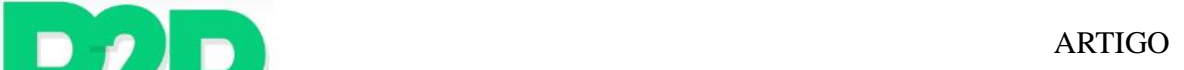

\title{
FROM THE COMMUNISM OF CAPITAL TO CAPITAL FOR THE COMMONS: TOWARDS AN OPEN CO-OPERATIVISM ${ }^{1}$
}

\section{Michel Bauwens}

Michel Bauwens is the founder of the Foundation for Peer to Peer Alternatives (P2P Foundation). Among others, he is one of three co-founders and partners of the Commons Strategies Group and, in 2014; he functioned as the research director of the FLOK Society transition program in Ecuador. (michel@p2pfoundation.net).

\section{Vasilis Kostakis}

Vasilis Kostakis (PhD, MSc, MA) is a political economist and founder of the P2P Lab. He is a research fellow at the Tallinn University of Technology as well as a collaborator of the P2P Foundation. (vasileios.kostakis@ttu.ee).

\begin{abstract}
Two prominent social progressive movements are faced with a few contradictions and a paradox. On the one side, we have a re-emergence of the co-operative movement and worker-owned enterprises which suffer from certain structural weaknesses. On the other, we have an emergent field of open and Commons-oriented peer production initiatives which create common pools of knowledge for the whole of humanity, but are dominated by start-ups and large multinational enterprises using the same Commons. Thus we have a paradox: the more communist the sharing license used in the peer production of free software or open hardware, the more capitalist the practice. To tackle this paradox and the aforementioned contradictions, we tentatively suggest a new convergence that would combine both Commons-oriented open peer production models with common ownership and governance models, such as those of the co-operatives and the solidarity economic models.
\end{abstract}

\section{Keywords}

Ethical Economy, Commons, Free Software, BusinessModels, Legal, Peer Production, Peer Property, Peer Production License, Co-operatives.

\section{DO COMUNISMO DE CAPITAL AO CAPITAL PARA OS COMUNS: PARA UM COOPERATIVISMO ABERTO}

\section{Resumo}

Dois importantes movimentos sociais progressistas enfrentam algumas poucas contradições e um paradoxo. Por um lado, temos a reemergência do movimento cooperativo e empresas pertencentes a trabalhadores que sofrem de certas vulnerabilidades estruturais. Por outro lado, temos uma área de atuação que emerge de iniciativas abertas $e$ orientadas por um processo colaborativo (peer production) de trabalhadores designados Comuns que criam redes comuns de conhecimento para toda a humanidade, mas são dominadas por startups e grandes empresas multinacionais que usam os mesmos Comuns. Assim temos um paradoxo: quanto mais comunista o compartilhamento sob a mesma licença usado no processo colaborativo (peer production) de software livre ou hardware aberto, mais capitalista é a prática. Para enfrentar tal paradoxo e as contradições já mencionadas, como tentativa sugerimos uma nova convergência que combinaria tanto os modelos orientados aos Comuns e abertos de

1 Available in: TripleC 12(1): 356-361, 2014. http://www.triple-c.at/index.php/tripleC 
colaboração peer production de posse comum, quanto modelos de governança, tais quais aqueles das cooperativas e os modelos econômicos baseados na solidariedade.

\section{Palavras-chave}

Economia ética. Commons. Software livre. Modelos de negócio. Legal. Peer Production. Peer Property. Peer Production License. Co-operatives.

A few contradictions can be observed in the modern progressive social movements.

On the one hand, we are witnessing a re-emergence of the co-operative movement and worker-owned enterprises (RESTAKIS, 2010). However, they arguably suffer from certain structural weaknesses. The co-operative entities work for their own members and, thus, are sometimes reluctant to accept new co-operators that would share existing profits andbenefits. In addition, they are practitioners of the same proprietary knowledgeand artificial scarcities tactics as their capitalist counterparts. That is, they might adopt monopoly pricing mechanisms such as those enabled by exclusive intellectual property rights. Moreover, even though they are internally democratic, they often participate in the same dynamics of capitalist competition whichcontradicts and, in the long run, may undermine their own co- operative values.

On the other hand, we have an emergent wave of open and Commons-oriented peer production efforts in fields such as free software, open design and open hardware, which docreate common pools of knowledge for the wholeof humanity. Nevertheless, at the same time they are dominated by both start-ups and large multinational enterprises exploiting andcapitalizing on the same Commons. In other words, peer production functionswithin the cycle of accumulation of capitalbut also within the new cycle of the creationand circulation of the Commons (Bauwens 2013). Today the egalitarian potentialof the Commons-based peer production seems promising but also the possibility for a parody should not be negligible (KOSTAKIS; STAVROULAKIS, 2013).

Therefore, we need a new convergence or synthesis, an "open co-operativism" if you like, that would combine Commons-oriented open peer production models with common ownership and governance modelssuch as those of the co-operatives and the solidarity economic models. What follows is a more detailed argument on how such a transition could be achieved. 


\section{PARADOX}

Today we have a paradox the more "communist" the sharing licensewe use (that is, norestrictions on sharing) in the peer production of free software or open hardware, the more capitalist the practice (that is, multinationals can use it for free). Take for example the Linux Commons which has become a corporate Commons as well, enriching big, for-profit corporations such as IBM (KOSTAKIS; BAUWENS, 2014). It is obvious that this works in a certain way and seems acceptable to most free software developers. But is this the optimal way?

Indeed, the GeneralPublic License and its variants allow anyone to use and modify the software code (or design), as long as the changesare integrated back in the common pool under the same conditions for further users. Our argument does not focus on the legal, contractual basis of the GPL and similarlicenses, but on the social logic that they enable, which is: it allows anybody to contribute, and it allows anybody to use. In fact, this relational dynamic is technically a form of "communism": from each accordingto his/her abilities, to each according to his/her needs. This paradoxically allows multinational corporations to use the free software code for profit maximization and capital accumulation. The result is that we do have an accumulation and circulation of information Commons, based on open input, participatory processes, and Commons-oriented output; but it is subsumed to capital accumulation. Therefore, currently it is not possible, or at least easy, to have social reproduction (that is, to create sustainable livelihoods) within the sphere of the Commons. The majority of the contributors participate on a voluntarybasis, and those, who have anincome, make a living either throughwage-labor or alliances with capital-driven entities.

Hence the free software and culture movements, however important they might be as new social forces and expression of new socialdemands, are also, in essence,"liberal" in the tradition of the politicalideology of liberalism. This is not only acknowledged by key figures such as Stallman, but also by anthropological studieslike those of Coleman and others (COLEMAN; GOLUB, 2008; COLEMAN; HILL, 2004). We could say they are liberal- communist and communist-liberal movements, which create a "communism of capital".

The question is whether Commons-based peer production, that is, a new proto-mode of production, can generate the institutional capacity and alliances needed to break the political 
power of the old order. Ultimately, the potential of the new mode is the same as those of the previous proto-modes of production - to emancipate itselffrom its dependency on the old decaying mode, so as to become self-sustaining and thus replace the accumulation of capital with the circulation of the Commons. An independent circulation of the Commons, where the common use-value would directly contribute to the furtherstrengthening of the Commons and of the commoners' own sustainability, without dependence on capital. How could this be achieved?

\section{ALTERNATIVE}

Is there an alternative? We believe that there is: to replace the non-reciprocal licenses, that is those which do not demand a direct reciprocity from its users, with one based onreciprocity. You may consider it as a switch from "communist" to "socialist licenses" or a swift from nonreciprocal licensesto a Commons-based reciprocal license (for a discussion of reciprocity in relationto licensing see de Filippiand Vieira 2013). We argue that the Peer Production License (PPL), designed and proposed by Kleiner (2010), exemplifies this line of argument. PPL should not to be confused with the Creative Commons (CC) non-commercial (NC) license, as its logic is different.The CC-NC offers protection to individuals reluctantto share, as they do not wish a commercialization of their work that would not reward them for their labor. Thus, the CC-NC license stops the further economicdevelopment based on this open and shared knowledge, and keeps it entirely in the not-for-profit sphere.

The logic of the PPL is to allow commercialization, but on the basis of a demandfor reciprocity. It is designed to enable and empower a counter-hegemonic reciprocal economy that combines Commonsthat is open to all that contribute, while charging a license fee for the forprofit companies who would like to use it without contributing. Not that much changes for the multinationals in practice; they can still use the code if they contribute, as IBM does with Linux. However, those who do not contribute should pay a license fee - a practice they are used to. Its practical effect would be to somehow direct a stream of income from capital to the Commons, but its main effect wouldbe ideological, or if you like, value-driven.

The entrepreneurial coalitions that are linkedaround a PPL-based Commons would be explicitly orientedtowards their contributions to the Commons, and the alternative value system that it represents. From the point of view of the peer producers or commoners, a Commons-based reciprocal license, like PPL, would allow the contributory communities tocreate their own co- 
operative entities. In this new ecology, profit would be subsumed to the social goal of sustaining the Commons and the commoners. Even the participating for-profit companies would consciously contribute under a new logic. This proposal would link the Commons to an entrepreneurial coalition of ethical market entities (co-ops and other models) and keep the surplus value entirely within the sphere of commoners/co-operators, instead of leaking out to the multinationals.

In other words, through this convergence or rather combination of a Commons model for the abundant immaterial resources, and a reciprocity-based model for the "scarce" material resources, the issue of livelihoods and social reproduction could be solved.The surplus value would be kept insidethe Commons sphere itself. It is the co-operatives that would, through their co-operative accumulation, fund the production of immaterial Commons, because they would pay and reward the peer producers associated with them.

In this way, peer production could move from a proto-mode of production, unableto perpetuate itself on its own outside capitalism, to an autonomous and real mode of production. It would create a counter-economy that could be the basis for reconstituting a "counter-hegemony" with a for-benefit circulation of value. This process, allied to "pro- Commons" social movements, could be the basis of the political and social transformation ofthepolitical economy. Hence we might move from a situation in which the communism of capital is dominant, to a situation in which we have a "capital for the Commons", increasingly insuring the self-reproduction of the peer production mode.

For the moment, the PPL is used experimentally by "Guerrilla Translation!" and is being discussed in various places, such as in some French open agricultural machining and design communities (for example, in the ShareLex initiative). Also the team of the P2P Lab in Greece is discussing the use of the PPL in the second versionof its collaborative theatrical play platform named "Wikitheater". The "man with the spottedtie" is probablythe first play written on a wiki through asynchronous and distributed collaborative processes (for a full account of the initiative see Kostakis and Drechsler 2013). The text was firstlypublished in 2012 under a modifiedCC license: everybody was free to perform the play and use its soundtrack music for non-profit purposes. In a case of a for-profit usage, the creative team of the P2P Lab would negotiate on a case-by-case basis. With a modified license which offered negotiated reciprocity, the authors and 
musicians have managed to accumulate a small capital, now used to support the creation of an international wikitheater platform and the translation of "the man with the spotted tie".

The new open co-operativism would be substantially different from the previous form. In the old one, internal economic democracy is accompanied by participation in market dynamics on behalf of the members, using capitalist competition. There is an unwillingness to share profits and benefits with outsiders, hence, no creationof the Commons. We argue that an independent Commons-oriented economy should be in need of a different model in which the co-operatives produce Commons and are statutorily oriented towards the creation of the common good. To realizetheir goals they should adopt multi-stakeholders formsof governance which wouldinclude workers, users-consumers, investors and the concerned communities.

As said, today we have a situation where open communities of peer producers are largely oriented towards the start-up model and are subsumed to profit maximization, while the cooperatives remain closed, use exclusive intellectual property licenses, and, thus, do not create a Commons. In the new model of open co-operativism, a merger should occur between the open peer production of Commons and the co-operative production of value. The new open cooperativism would: i) integrate externalities; ii) practice economic democracy; iii) produce Commons for the common good; iv) and socialize its knowledge. The circulation of the Commons would be combined with the process of co-operative accumulation, on behalf of the Commons and its contributors. In the beginning, the immaterial Commons field, following the logic of free contributions and universal use for everyone who needs it, would co-existwith a cooperative model for physical production, based on reciprocity. But as the co-operative model would be becoming more and more hyper-productive beingable to createsustainable abundance in material goods, the two logics would merge.

\section{DISCUSSION}

Our proposal distinguishes the sphere of the abundantCommons, and the sphere of cooperatives and ethical companies which deal with the allocation of scarce resources. The two spheres converge in the workers who are both contributors to the Commons and realize their livelihood in the co-operative sphere. Of course, there is no doubt that the capitalist power can severely impede the co-operative economy. As a result, the co-ops may often exaggerate their 
adaptation to the capitalist system. This is precisely why we proposethe concept ofopen cooperativism, which can be seen as a new form where the link to the Commons and the common good is constitutionally obligatory.

Furthermore, capital understands the hypercompetitive and hyperproductive nature of peer production, and invests in it. That is why we believe that the ethical Commons-oriented coalitions, which would produce, protect and use their Commons through reciprocity licenses, could gain an extraordinary competitive edge. While the GPL licenses effectively enable a social logic of unlimited use, this includes use by multinational companies. The PPL restricts it. Of course, we do not take the PPL as perfect, but as a new kind of Commons-based reciprocity licenses, whose detailed modalities can very well differ from the original PPL. Such licenses would fully allow commercial exploitation, but ask for reciprocity.

Take for examplea traditional indigenous community using a GPL or a similarlicense. This means any commercial entitycould use the knowledge and commercialize it, without any benefit or profit sharing with the creators of the knowledge. A Commons-based reciprocity license would simply ask for reciprocity and would allow these traditional communities to generate autonomous living and livelihoods, something which is harder to do with the GPL. Furthermore, a Commonsbased reciprocity license would not prohibit commercial exploitation but actually encourage it, while the non-commercial licenses prohibit it. The latter do not undermine sharing, but commercialization. While the PPL/Commons- based reciprocity licenses would encourage and allow both sharing and commercialization.

In fact, there is only self-determination of the contributory process in the GPL context, but full alienation to the capital in the surrounding commercialsphere. By contrast, the PPL not only allows full self-determination in the contributory sphere, but also requires self- management in the co-operative sphere of self-reproduction. This is much more difficult with the GPL, since it subsumes livelihoods to capital accumulation. Moreover, the GPL does not demand nor create directreciprocity between people.It is entirely possible to use GPL material without any reciprocity, as the overwhelming majority of its users actually do. But the GPL requires what anthropologists call "general reciprocity", that is at the collectivelevel, a minimum of contributions is needed to sustain the system. Nevertheless, there is absolutely no requirement for direct reciprocity. The reciprocity is between the individual and the system as a whole. A coder or 
Wikipedia contributor cannot expect any return from any particular individual but only expects the benefits of the whole system, which depend only on a general flow of contributions.

On the other hand, the PPL/Commons-based reciprocity licenses would indeedlimit the non-reciprocity for for-profit entities; however, they would not demand equivalent exchange, but only some form of negotiated reciprocity. The important aspect is to generate a flow of realized value, necessary for social reproduction, from the sphere of capital accumulation to the sphere of the Commons. The second aspect is organizational. The PPL arguably promotes the selforganization of an ethical economy, and makes those who want to join it, conscious of that fact (including for-profit companies which can decide to ally with the ethical entrepreneurial coalition).

It is important to highlight that the Commons-based reciprocal licenses, like PPL, are not merely about redistribution of value, but about changing the mode of production. Our approach is to transformreally existing peer production, which is today not a full mode of production being incapableof assuring its own self-reproduction. This is exactlywhy the convergence of peer production in the sphere of abundance must be linked to the sphere ofco-operative production, and thus insure its self-reproduction. Like in any pastphase transition, the existence of a protocounter-economy, and the resources that this allocates to the counter-hegemonic forces, are absolutely essential for a political and social change. This was arguably the weakness of classic socialism, that is, it had no alternative mode ofproduction, and could only institute state control after a takeover of power.

In other words, it is difficult, if not impossible, to wait and see the organic and emergent development of peer production into a fully alternative system. If we follow such an approach, peer production would just remain a parasitic modalitydependent on the self-reproduction through capital.We argue that the expectation that one can change the society, by merely producing open code and design, while remaining subservient to capital, is a dangerous pipe dream. By contrast, throughthe ethical economysurrounding the Commons, it becomes possible to create non-commodified production and exchange.

We thus envisiona resource-based economywhich would utilizethe stigmergic mutual coordination through the gradual application of open book accounting and open supply changes. We deem that there will be no qualitative phase transition merely through emergence, but it will require the reconstitution of powerful political and social movements which aim to become a 
democratic polis. And that democratic polis, could indeed, through democratic decisions, accelerate the transition. It could take measures that force private economic forces to includeexternalities, thereby endinginfinite capital accumulation.

\section{CONCLUSION}

The key argument of this article was the following: the current fully-sharing open licenses which allowunrestricted commercial exploitation create a communism of capital, that is asphere of open knowledge, code and design, which is subsumedto the present dominant political economy. But what we need is an autonomous sphere of peer production, in which commoners and peer producers can create their own livelihood, while staying in the sphere of the Commons. In other words, we need capital for the Commons realizing through a newtype of licensing. We are in favour of the PPL, not in its full detail, but as a first of a kind of aCommons-based reciprocal license that encourages commercialization, but transforms it into an ethical economy.In that way it becomespossible to convergethe sphere of immaterial Commons contributions with a sphere of co-operative accumulation, through which the surplus value can stay within the sphere of Commons/co-operative production.

\section{REFERENCES}

BAUWENS, Michel. Thesis on Digital Labor in an Emerging P2P Economy. In: Digital Labor. The Internet as Playground and Factory. Edited by Trebor Scholz. New York: Routledge, 2013. p. 207-210.

COLEMAN, Gabriella. The Political Agnosticism of Free and Open Source Software and the Inadvertent Politics of Contrast. Anthropological Quarterly n. 77 (3), 2014. p. 507-519.

COLEMAN, Gabriella; GOLUB, Alex. Hacker practice: Moral genres and the cultural articulation of liberalism. Anthropological Theory n.8 (3), 2008. p. 255-277.

COLEMAN, Biella; HILL, Mako. How Free Became Open and Everything Else Under the Sun. M/C Journal: A Journal of Media and Culture, 7, 2004. Available in: 
<http://journal.media-culture.org.au/0406/02_Coleman-Hill.php〉. Accessed April 1, 2014.

FILIPPI, Primavera de; VIEIRA, Said. 13. The Commodification of Information Commons. In: Proceedings of the 1st Global Thematic IASC Conference on the Knowledge Commons, Building Institutions for Sustainable Scientific, Cultural and Genetic Resources Commons. Université Catholique de Louvain, Louvain-la-Neuve: Belgium, 2013. Available in: < http://biogov.uclouvain.be/iasc/doc/full\%20papers/De\%20Filippi\%20-\%20Said\%20Vieira.pdf>. Accessed 1 april 2014.

KOSTAKIS, Vasilis; BAUWENS, Michel. Network Societyand Future Scenarios for a Collaborative Economy. London: Palgrave Macmillan (forthcoming), 2014.

KOSTAKIS, Vasilis; STAVROULAKIS, Stelios. The Parody of the Commons. TripleC Communication, Capitalism \& Critique: Journal for a Global Sustainable Information Society n.11 (2), 2013. p. 412-424.

KOSTAKIS, Vasilis; DRECHSLER, Wolfgang. Commons-based Peer Production and Artistic Expression: Two Cases from Greece. New Media \& Society, 2013. Available in: < http://nms.sagepub.com/content/early/2013/11/14/1461444813511929.abstract>. Accessed April $1,2014$.

KLEINER, Dmytri. The Telekommunist Manifesto. Amsterdam: Institute of Network Cultures, 2014.

RESTAKIS, John. Humanizing the Economy: Co-operatives in the Age of Capital. Gabriola Island, New Society Publishers: Canada, 2010. 